Brandeis $\mid$ urearar

brandeis.edu/j-caste
CASTE: A Global Journal on Social Exclusion Vol. 2 No. 2 pp. $407-410$

October-November 2021

ISSN 2639-4928

https://doi.org/10.26812/caste.v2i2.347

\title{
Caste, Gender and Fire in Maadathy: An Unconventional Fairy Tale
}

\author{
Reviewer: Roja Suganthy-Singh \\ Department of Sociology, \\ St. John Fisher College, Rochester, NY \\ E-mail: rojasingh3@gmail.com
}

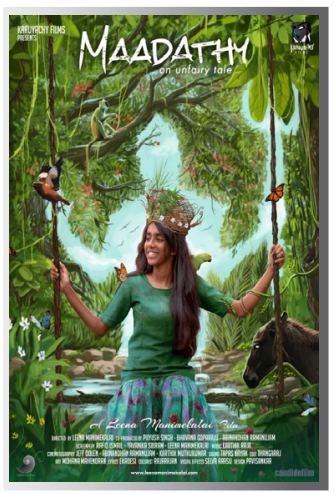

Maadathy: An Unfairy Tale directed by Leena Manimekalai, a crowd-funded production pioneered by Bhavana Goparaju is one of the most riveting feature film releases in 2021 in the global film world. Exposing the monstrosity of the intersections of caste and gender in India, the film was a Jury award winner in 2020 and a nominee for the Kim Ji Seok award in 2019. Made in 2018 but officially released in 2021, it is a story in itself of awry patriarchal media authoritarianism in India. Viewers can watch the film on neestream.com and upcoming on Amazon Prime as well.

The film focuses on a family from the Puthirai Vannar referred to as the "unseeables" - a sub-community of Dalits, the outcastes in India. Vannar are launderers hired to wash the clothes of the dominant caste and other Dalit communities, including menstrual cloths. They are not allowed to be seen and are expected to stay hidden from the dominant caste. However, those very eyes pillage these women and children exercising selective "visibility" and selective "touchability" upon their bodies. It is that everyday politics of vision in that "seeing" and "being seen" activity we are appalled by in the film. Irreversible rules of eye-to-eye contact and eye-to-body contact are the forbidden acts that the Vannar community should bear the burden of safeguarding, while the dominant caste men establish their prerogative to break on their own terms; their eyes cannot lock but bodies do.

We first hear the story of this community in the novel Koveru Kazhuthaigal by Imayam in 1994 (translated as Beasts of Burden). Imayam tells the story of a Vannar family who constantly slide into economic and physical mires unable to retrieve their sinking selves. As Imayan suggests, everyone finds pleasure in feeling above somebody else, whatever that momentous pleasure maybe. 
C. Lakshmanan and K. Raghupathy's work, Theedamaikkul Theendaamai: Puthurai Vannar Vaazhvun Irappum, 2017 (Untouchability within Untouchability: The Life and Death of Puthrai Vannar) is one of the few research-based books on this community.

Seeped in an organic methodology of participatory cinema, Manimekalai combines history, fact and life presented in Dalit Tamil (with English subtitles) as she grapples heavy themes, such as caste, gender and communal hierarchy that strangulate, rape and murder women. The film is based in an ethereally fantastical village, home to Puthirai Vannar in South India, tucked into breathtaking mountains, waterfalls, river and forest that the cinematography unfurls. She secured training for her actors from the Vannar community with whom they stayed for the entire film production. Such expert knowledge and lived experiences of the community, brings us closer to the truth that under such innocuous beauty, lurk pursuing perils. In the filming process, the Vannar community share their social condition-that if you are a Dalit Vannar woman, you will be raped as an everyday routine (Manimekalai, 2021). In the partnership between caste hierarchy and a much older globally normalized scriptural ordinance of patriarchal authority - the precursor to imposed caste, race and gender identities - pre-determine a Vannar girl's life and death. Like young Yosana (Tamil word for thought) in the film, Dalit girls are victims of sexual violence made permissible in a dominant caste-driven patriarchal ideology which I will call patria-caste that does not spare recruiting Dalit men into their patriarchate. The All India Dalit Mahila Adhikar Manch Delhi, India states 16,236 reported cases of rape of Dalit girls and women in 2014-2019. Rape of minor Dalit girls is recorded at 2,642 in 2017-2019, in just three years. Of course, there are numerous unreported cases. This aspect is highlighted in the careful planning that involves teamwork whether it is rape carried out by a single man or multiple men, both of which the film depicts. Powerful structures of governance set already wounded Dalit men against one another, kicking them onto a survivor wrestling ground to grab a few rupees. The Vannar men's experiences of dominant caste men who manipulate their vulnerable sub-ordinate masculinity as prime meat, instigating anger and mistrust against their own, is clearly layered for the viewer. As stated by the Vannar community, Leena brings into the film, women in dominant caste communities as well who seek their own victim-erasure in securing superiority over Dalit men, women, and other gender identities.

The heart-wrenching acting by Semmalar Annam as Veni, maps numerous points of geographies of fear that the Vannar women should but cannot avoid and geographies of refuge that fail to protect these women and children. The cartographers comprise actors across territorial, religious and caste boundaries, using women's bodies to announce acidic patria-caste intertwining of entitled settler syndromes in their self-declared occupation of those sacred spaces. In the film, Veni laments to her father-in-law, "When I think of Yosana's future, I feel fire in my lap." He responds, "Of course. It is natural. Your mother, grandmother and your great grandmother. It is the fire in the lap of all the women." Veni anguishes, "She keeps wandering like a wild bird. I am struggling so hard to protect her." The sacrilege of mental and bodily spaces leaves the Vannar women emotionally, psychologically and physically maimed for generations as they go about their everyday chores carrying "fire on their laps" (Maadathy). The destruction of bodies, families and minds continue as due processes of planting flagpoles of male dominance on beautiful bodies and reciprocal territories resulting in trauma. Yosana's bold curiosity of the geographies of her own body, 
nature's incarnations and the male body turns into a punishable crime and her sweetcrush is crushed by the hurt male ego that needs quenching.

The producers, along with Leena Manimekalai are to be highly commended for producing a film that was bound to face hurdles. The team dared to render visible the story of Dalits cornered in invisible spaces where intersectional nodes of caste, class, religion and gender identities leave women bare and bleeding. Co-habiting with danger, Dalit women's bodies are a hunt for all men irrespective of caste identity who find solidarity with dominant castes in replicating hegemonic masculinity as a cultural normative. Zora Neale Hurston's words echo as we watch this film: "De nigger woman is de mule uh de world" (Their Eyes were Watching God, 1937.) Socially shunned women are the ones sought for work, sex, and dehumanization. The film compellingly reveals the complexity of the tragedy that lies in the alluring trap of alcohol and toxic masculinity doled out in conniving ways by dominant caste members that Dalit men fall prey to- a patria-caste.

Young Yosana, brilliantly and captivatingly played by Ajmina Kasim, revolves around us in this film, enjoying a caressing closeness with nature as water plays on her body. Water is simultaneously alive, dead, peaceful, turbulent and ghostly as a gurgling bearer of blood oozing from body and mind carrying "pollution" and "purity" all at once. Yosana is a talking friend to animals and birds in her universe. The scenes where Yosana and nature's other beings coddle in feeding a pomegranate to monkey friends are delightful and moving when the baby donkey-friend, an extension of her innocence, faithfully reciprocates her kindness. Yosana claims her natural right to admire nature almost as a fixation and provides copyright to that natural world to own her in a reciprocity that is fairytale-like. Her mother complains, "Is this your only chore? Feeding the rabbits, singing to the quails. Who will marry you?" As a free wanderer, and water lover, wading in the gorges by the river, she desirously gazes, touches a forbidden male body with her gaze, and steals his smell to quench her confused response to a sexual awareness. Unfortunately, it is that same innocent curious admiration that allures her into a cave-tomb where her mother's fear comes true. Ever since Yosana emerged from her womb as a girl, a Dalit girl, a Dalit Vannar girl - she knew that the stars lined up in that order to determine her fate.

Yosana trustingly crawls into the crevices of our thoughts and emotions demanding our affection and attention, leaving us restlessly feeling untrustworthy. She comes to stay whether you like it or not, but you will. She drags you along with her into a vivacious innocence that moves you to fall in love with her with an ease as cotton flies from the trees we are shown. You most certainly will smile, laugh and cry with her. The merging of the natural elements with the supernatural carries Leena's talent to a level of genius storytelling. The duplicity of a dialectical opposition of "to be seen" or "not to be seen" as a human being, is intentionally reified in Yosana. She hurriedly runs away from the simultaneity of deification, but the viewer cannot escape the unfolding of the hypocrisy of deity devotees who will construct and destruct female bodies to score in that ruthless game of a culturally normalized and socially perpetuated ritual of rape. The real tragedy is the infiltration of that dangerous combination of casteist patriarchate into oppressed groups who look for the Other to readily exercise power upon. Are not all who carry such exhibitions of masculinity and caste power both explicitly and implicitly, complicit? The film disallows us as we become desperate to magically remove our omnipresence in this story. We are haunted by our own ghosts with whom we play hide and seek in our hidden crevices. 
With powerfully placed symbolism in colors, body fluids, water, eyes, body and much more, Leena weaves her own magical web of a genre where she but leaves the facts as frozen droplets on those strands, mesmerizing the viewer in its multidimensional intersectional layers. Each leaf, sound, sweat drop and each hurl of the hand beating the clothes on the stone, the washer woman's pressing feet into menstrual blooded clothes, stain our guarded minds as an unforgettable horror despite the scenic views. Human and non-human actors - both bleeding and unbleeding-blend like the colors on the canvas testifying to these hidden stories. Erasures of borders of the human and the spiritual worlds direct us to not just imagine a world free of caste borders, but a world where lessons ought to be learnt and put to praxis in nature's economy of un-exploitative and un-authoritative blending of task and be-ing. In the ruins of the temple (one of the many un-bleeding actors) we see a collapse of the marriage of capitalism and religious structures and in the hut where Yosana's divinity resides in a young new-generation-boy who shows the path to an empathetic casteless and genderless structure as he hands a cloth to a menstruating woman. Leena unfolds our eyes to follow Yosana's world of seeking justice alongside creating a counter world to vampirism that chases women, Dalits and all those vulnerable.

In this new genre of storytelling where "to be" or "not to be" or "to be seen" or "not to be seen" are not choices of a human or a ghost, but an anomalous state of being which through magical surrealism Leena exposes as devious reality. Maadathy webs diverse strings of genres where horror leaves us in disbelief that we ask ourselves "Can this be true today?" We are left in a state of helplessness - an unfamiliar place in nature, where the arduous yet beautiful terrains of the "unseeable's" isolated habitat of body and mind merge in explosions of new grounds where we hesitate to plant our feet in. However, we do follow playful Yosana, entranced but left with a feeling of being duped. We wonder as to who orchestrated that disappearing act of Snow White's apparitions that we were led by. Clearly, since that cinematization of binaries of good and evil in 1938, the dominant male is still on that quest for a tall-ego compensation through domestication of women by marking their forbidden territories as dangerous. Do we not know that patria-caste assumes many forms to allure little girls like Yosana with forbidden fruit, and a princess will fall? Princely powers stand by to violate a fallen princess while distant drums erect yet another deity: conventional fairy tale gone wrong, but a conventional caste tale gone mighty right. Yosana is bewitched by her choices of a free spirit and awareness of emotions and pays the price for plucking the forbidden fruit off a man's back.

Maadathy, a "must see" film, leads us to consider Shakespeare's Ophelia who lies torn at the junction of forbidden desire, blame, and all other Eurocentric canonization of ranked patriarchy that mangles women's bodies and minds. Ophelia drowns and Yosana rises flooding the film in several apparitional forms and in the clever allpervasive symbolic details. Yosana no longer just tenuously breathes but stands strong and tall as an incarnation of Maadathy to protect all vulnerable beings and exorcise the colluding forces of caste and patriarchy that seek a pan-camaraderie. Can she conjure a life of her choosing where geographies of fear will transform into safe homes for beautiful bodies and minds? Leena leaves us to imagine a new generation of kind boys and men who will choose a sincere mission of the deincarnation of patria-caste where a pariah parent can lull their sweet child on a fire-free lap and as she grows, can actually enjoy a swim with her daughter. 